Article

\title{
Improving the Impact of Green Construction Management on the Quality of Highway Engineering Projects
}

\author{
Xueying $\mathrm{Wu}^{1, *}$, Wenyi Zhao ${ }^{2}$ and Tianshan $\mathrm{Ma}^{1}$ \\ 1 School of Economics and Management, Chang'An University, Middle Section of South Second Ring Road, \\ Xi'an 710064,China; mtshan@chd.edu.cn \\ 2 School of Literature, Art and Communication, Chang'An University, Middle Section of South Second Ring \\ Road, Xi'an 710064, China; zwy@chd.edu.cn \\ * Correspondence: 2016023003@chd.edu.cn
}

Received: 9 March 2019; Accepted: 26 March 2019; Published: 29 March 2019

check for updates

\begin{abstract}
The implementation of green projects continues to encounter several challenges with regards to the project management techniques applied in different construction projects. This study aims to find out the relationship between green construction management and the quality of highway engineering projects, and to try to help innovators identify the best place to focus. This study adopted mixed research method where both quantitative and qualitative research approaches were used. The analysis techniques adopted included Pearson's correlation, regression analysis, and Student's t-test. The study found that the effect of financial issues, design codes and standards, and various risks will be the most effective green performance constructing strategies. It is revealed that there are eight determinants explained $77.5 \%$ of the variations in the quality of the highway engineering projects. The quality of highway engineering projects was expected to improve by 0.246 units for a unit change in the adoption of the green construction management. The research result will help stakeholders in improving the quality standards for highway engineering projects and help practitioners and experts in the construction project industry to better understand the relationship between green construction management and quality of highway engineering projects, and help them improve green construction management in an effort to promote sustainable development of project management. This research can be further studied in the future to expand the scope of data analysis to explain the differences in the level of social development.
\end{abstract}

Keywords: green construction management; highway engineering project; green construction project; green performance contracting strategies

\section{Introduction}

\subsection{Background Information}

The industrial dynamism in modern day development is a threat to environmental sustainability. There is a growing concern over the state of climate change and how the construction industry affects the framework to implement such change [1]. The implementation of green construction projects continues to encounter several challenges with regards to the project management techniques applied in different construction projects [1]. In essence, highway engineering projects face common challenges with regards to developing a sustainable project management plan that caters to the challenges, impacts and their solution.

The concept behind green construction lies far beyond the construction of buildings without harming the environment as it tries to establish the conditions that would eventually upgrade the 
quality of planet Earth [2]. In simple terms, green construction is defined as an attempt to build responsibly while reducing waste and helping preserve the environment. Research has highlighted the four processes involved in green construction as planning, construction, designing and conducting building operations with some critical, foremost considerations. The persons involved should consider the use of water and energy, the quality of the indoor environment, material section and the effect the building has on its site [2]. It is important to note that green construction technology is currently at the most advanced level than ever before, and as the supply of non-renewable resources in the world becomes rare and expensive, green technology continues to increases its significance.

Green construction management is the advancement of sustainable development through responsible management of portfolios, programs, and projects with the aim of achieving environment friendly structures. Green construction management is taking control of the processes involved in green construction namely planning, construction, designing and conducting building operations with critical as well as priority considerations [3]. Green construction management involves the development of strategies that may help in planning, directing, coordinating, and budgeting activities on the project site [4]. There is a need to develop material that focuses on the techniques to overcome barriers in the project management frameworks, thus fortifying the base for future green building projects in highway engineering. Hence, there is a need to practice the creation of structures and using processes that are environmentally friendly through the process of green building [3]. Green building refers to both a structure and the application of processes that are environmentally friendly as well as resource-efficient throughout the building process [3].

About 2.2 billion people in 108 countries face a risk of surviving on multidimensional poverty while an approximated proportion of $68.18 \%$ of the 2.2 billion people survive on or less than US\$ $\$ .25$ a day [5]. This highlights the concept of a green economy that would promote an attractive green revolution to the current crises that are affecting developing countries for sustainable environmental and economic improvement [5]. According to the research, one way of reducing the emissions released from fossil fuels and greenhouse gases is through the construction of green roads with carbon neutral materials [5].

Highway engineering projects contribute $25 \%$ to the total energy cost in any developing country [6]. The construction of highway projects has both commercial and residential implications [7]. The current ameliorating global concern on the damaging effects of construction activities on the environment is directed at promoting sustainable development as well as implementing green measures [7]. Countries are shifting their focus to making sustainable development a national priority. The clamor to implement green construction management techniques gained momentum at the beginning of the 21st century and has continuously escalated with time [7]. There has been an $80 \%$ increase in the green mark project certification in regional constituents such as in Europe and the greater Asian region and among other already developed countries [6].

Even though the new technologies are constantly being developed as complements to current practices in creating better and greener structures, the common objective of green construction projects is to minimize the overall impact of the built environment on the natural environment and human health [4]. The dissimilarities in the quality of the highway engineering projects exist in the level of details emphasized in each project [4]. Additionally, the paucity in green construction management lacks knowledge sustainable with reference to how it limits project performance [8]. Looking ahead, highway and transport infrastructure is expected to face increasing pressures and impacts from a range of issues including changing weather patterns, capacity constraints, population growth, land and capital shortage, and rapidly changing technology that is outstripping the pace of new infrastructure development. Also, the expected change in travel behaviors will also impact highway construction projects and transportations greatly. Notably, different nations have approached the problem of global warming and depletion of natural resources differently. Malaysia, for example, has adopted a lot of alternative pavement materials as well as technologies that have been brought to the construction industry with the aim of achieving green highways [9]. However, there is still much room for 
improvement and researchers have been called upon to dig deeper into the issue. The sustainability concept in highway development needs to be addressed critically so as to eliminate the effect of global warming and depletion of issues of natural resources [9].

This research investigates the green construction management making close reference to the impact on the quality of highway engineering projects. The methodology used in the study is mixed in nature with evidence from 200 respondents from construction companies which had been involved in at least one highway engineering project for the past 10 years. Additionally, the literature review gathers information from different peer and scholarly-reviewed material.

\subsection{Possible New Situations in Which Mobility Will Change}

There is sufficient evidence from the available literature that green construction is likely to re-shape the future of locomotion systems and what currently exists will be transformed. There will be increased safety, unprecedented level of comfort as well as a gain in personal time [10]. In addition, there will be potential effects of the technologies such as green construction on the climate. Reports indicate that today, locomotion systems are responsible for almost $25 \%$ of global $\mathrm{CO}_{2}$ emissions, with road traffic accounting for the biggest proportion of $17.5 \%$ [11]. In another case, the diesel scandal in Germany which was triggered in 2015, significantly revealed the emission of nitrogen oxides which are known to be harmful to the environment [12]. Nonetheless, in light of all these negative consequences for the climate and the associated air pollution, the development of the green construction and other new technologies promises a sustainable future of new mobility which will potentially protect the climate and environment.

\subsection{Research Justification}

This research will help stakeholders in understanding the most effective green performance constructing strategies which will enhance improvement processes. Also, the research will help in revealing the determinants of the quality standards for highway engineering projects. The findings will, therefore, help stakeholders in ensuring high quality of the highway projects. The current contracting practice for addressing climate change issues will be addressed where the most effective green performance contracting strategies will be evaluated. Moreover, the findings of the study will act as background information to future researchers who will intend to conduct further research on green construction management and its impact of highway engineering projects or related topic.

The research questions guiding the study are:

(1) Which are the most effective green performance constructing strategies?

(2) What are the determinants of the quality standards for highway engineering projects?

(3) To what extent does green construction management improve highway engineering projects?

\section{Literature Review}

The design, construction, maintenance, operation and regulation of major transport passages such as roads, bridges and tunnels has an effect on the socio-economic status of the communities around them [13]. Aside from the socio-economic influence of highway engineering projects on the communities, the projects have considerable influence on the ecological state of the community [14]. In essence, it is imperative that the construction teams take into consideration the project life cycle, the material used in construction, and pre-construction and post-construction activities attributed to the project [14]. Require proper management if the response is targeted at reducing the impact of the constriction on the immediate community as well as the environment.

\subsection{Green Construction Management}

Green construction management ensures the incorporation of both convectional construction principles as well as green construction management technique [15]. The goal of green construction 
management is to enhance the sustainability of projects. Green construction project calls for the adoption of the use recyclable material that offer similar level of fortification and use as the convectional material [16]. The contractor as well as the project managers must decipher techniques that ensure the level of pollution throughout the construction is minimized [17]. Techniques in green construction management promote the reduction of soil erosion, an improvement of the waterway sedimentation and the control of airborne dust generation [18]. The general goal of green construction management is to promote the general state of the environment and thus limit the disturbance to the environment $[3,19]$. In essence, the aforementioned considerations are in most cases overlooked in matters relating to the convectional construction management.

The commissioning of green construction management, as well as the projects involved varies from country to country. The variation depends on the intensity of the environmental concern channeled by the institutions of governance $[20,21]$. Strict issuance of the green mark or third party certification is thereby more complex in countries that exert more concern on green construction and maintenance.

Green construction management has, to a large extent, improved highway engineering projects. Green construction management helps in achieving sustainability and improved quality [13]. This is because sustainability is a natural part of the project management discipline under the green management. Project management entails the reduction of costs while increasing the value and protecting scarce resources [15]. Through the green construction management, managers are made to think beyond the confines of their project to consider the entire life cycle of the projects. Also, the ultimate sponsors, the users and the expanded set of stakeholders including those who will inherit the environment in the long term are considered in green construction management leading to an improvement in projects.

\subsection{Highway Engineering Projects}

Highway engineering projects require a sophisticated level of art and skill, more so if the construction happens within close proximity to any human or wildlife population [15]. Highway engineering projects are constantly surpassing existing expectations and natural limitations. Ever since the adaptation of the Macadam road construction strategies in the 1900s the construction of highway projects transcends both time in the effort of improving on new generations [22]. The construction of some of the most sophisticated highway projects such as the Qingdao Haiwan Bridge contain both convectional Roman road ideals as well as the industrialized modern road structures [23]. The advance of technology has consequently brought up better ways of conserving energy through the fastened rate of construction and maintenance [24]. In more industrialize and developed countries such as the USA, highway engineering is a crucial discipline cemented with the enactment of the United States Highway Act of 1944 [25]. The Federal-Aid Highway Act of 1944 aimed at connecting approximately 91\% of cities with a population of 55,000 [26,27]. However, the discipline is countered by constant stress from vehicles that have over time grown larger. In addition, improvements to pavements were needed for the growing population that constantly required the government to step up their socio-economic status as well reduces the number of accidents caused by the lack of pedestrian pathways [28]. The total annual road expenditure across the world is shown in Figure 1. From the review of the literature, it is evident that the total annual road expenditure has an exponential growth rate regardless of whether the contractors use green construction management techniques or convectional approaches. 


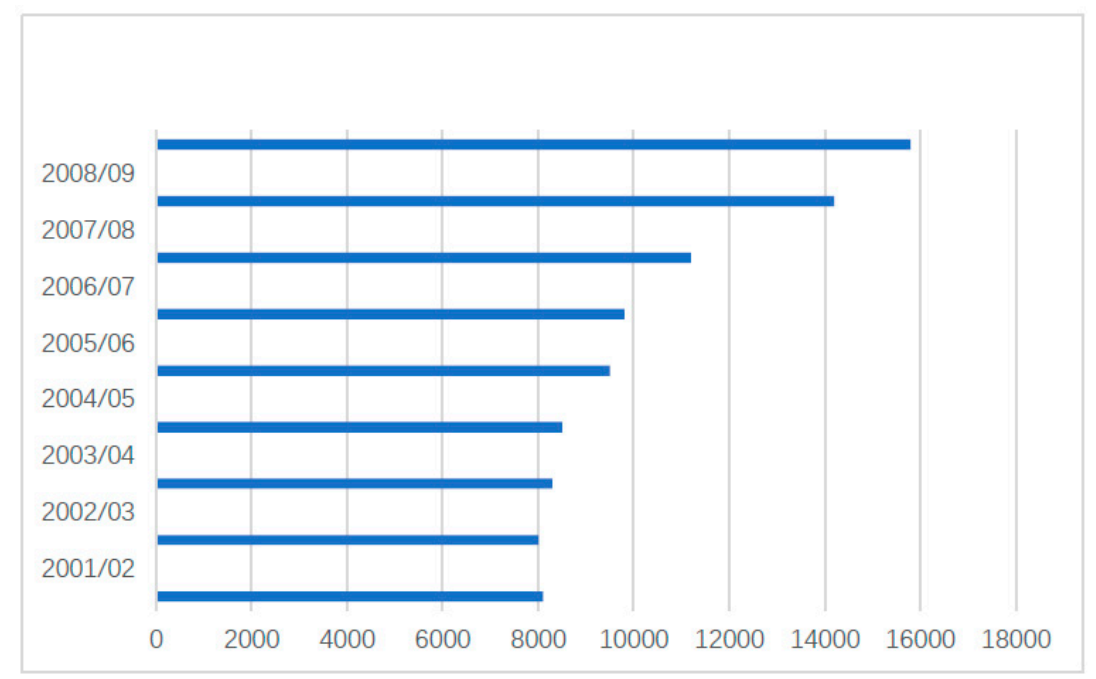

Figure 1. Total annual average road expenditure around the world [29].

\subsection{Innovation Using Green Construction}

The call for more energy-efficient forms of development is geared towards promoting sustainability and a boost to innovation [30]. Green construction technologies offer a more efficient way of erecting large products with the state of the environment in mind. Aside from the introduction of green construction in public works as an effort by various governments under the advice of various environment and strategy experts, the introduction of the suggested green construction projects are directed towards improving on the innovative capacities of society [31]. The use of proactive innovation technologies in green construction has led to the shrink in energy consumption and a decrease in the carbon footprint by convectional construction projects [25]. In London, the prospective innovation on green construction projects will initiate the refurbish of almost all construction projects in the city by the year 2020 [32].

The innovation in the green sector economy has led to the reduction of about $40 \%$ of the energy in circulation in the last 17 years [23]. The reduced energy is viewed greatly in the industrial and transport sector. In retrospect, the total amount of energy saved is roughly 20 exajoules each year [23]. The construction projects are responsible for $37 \%$ of the total energy and hydrocarbon emissions during transportation [23]. Improving on the energy and hydrocarbon emissions on highway construction projects has a trickling effect of promoting an efficiency-related construction market for future generations.

Innovative trends in green construction technology are believed to illustrate a positive exponential growth over the years [32]. The integration of innovation in green technology has introduced more efficient heating, ventilation and air conditioning systems, connecting systems such as elevators, over and underpasses among other highway project fittings [23]. The resultant effect of the improvement of the innovative technologies in green construction is the heightened patent filling procedures by various contractors.

\subsection{Challenges in Maintaining Green Construction}

The challenges attached to maintaining green construction involve three general aspects. First, green construction requires the identification of the different possibilities of the impact of highway construction on the natural as well as the socio-economic environment [13]. Second, green construction demands the evaluation and the quantification in terms of the scale and the time period of the effect of the construction [33]. Third, green construction management demands the consequent formulation of measures that mitigate and avoid the anticipated impact from the construction of the highway [13]. The design considerations include the sight distance, the lane width and the design traffic volume. 
However, there are other indirect factors such as the horizontal and vertical clearances that have an effect on green construction highway projects [34].

While the green construction development has become a trend in recent years, complexities rendered by the idea during the operational and maintenance phase often overshadow the benefits that may be realized through the development of green construction [35]. Several factors were highlighted by the researcher has being the major influencers of the complexities in managing and maintaining green construction. According to the study, managerial factors, environmental factors and biological factors were the major classifications of the factors causing the complexities [35].

First the heightened cost of green construction practices and materials limits the initial capital cost of green construction in highway projects. The higher costs are associated with high-cost materials as well as the high costs of green construction technologies [36]. Slow developing economies have no incentive to engage in green construction management. In most cases, the inclined costs associate with green construction management directly influences the project manager. The construction project managers are in charge of the management and delivery of the construction projects within the presented budget [15].

Second, there is credible evidence about the technical difficulties during green construction project processes. The efforts of the highway project planner are directed towards ensuring the success of officiating and implementing a green design highway plan that depends largely on the predisposition of contract construction agreement approved on the delivery of the highway project [37]. The full integration of green design may limit the number of potential contractors that apply or bid for the highway construction. The interlock of the green construction project design and the general project design may fail to hold. A greater percentage of the change compromised to the inauguration of the project is green features of the project [30].

Third, the lengthy approval of green technologies coupled with the constant supply of recycled materials is attributed to the market environment that is keen on the sustainability of the goods introduced in the market [37].

Additionally, the time required to fully integrate green designs challenges green construction project managers from developing a schedule that approves the payment to the vendors and suppliers [38].

Fifth, there exists the unfamiliarity with green construction technologies in most developing nations of the world. As mentioned above, green construction technologies pose greater challenges to the contractors, developers and the clients [39]. There is insufficient and uncertified knowledge on the technical expertise and product, materials, systems and designs allocated for green construction and designs. Green construction technologies are more complex as compared to traditional construction technologies [40]. The interest among team members is crucial as it determines the initial enthusiasm as well as the progress of the project.

Sixth, green construction management requires strong and constant communication among the project team members. There are a considerably larger number of subcontractors, team members and suppliers involved in the green construction projects. In essence, communication is imperative as it aids in maintaining the level of interest among the team members [41]. The initial enthusiasm involved in the separation of waste materials among sub-contractors should increase as the project progresses.

Seventh, time is a restraint factor when it comes to green construction management. There are random checks and frequent on-site visits by green construction project managers. The regularized check-up is crucial in determining the progress of the structures in place [42,43]. The time frame available for green construction projects is not clearly defined as there are different performance rates of different projects.

\subsection{The Green Performance Contracting Strategies}

In accordance with the emission sources and applied project phases addressed by the strategies, green performance contracting strategies have been classified into four levels namely the material 
related, equipment and energy efficiency, green life cycle, and clean energy development strategies [44]. Under the material related strategies, the focus is more on the reduction of the effect of greenhouse gas emission using material related approaches. The approaches mainly include recycling or reusing, treatment, and life cycle management.

On the other hand, the equipment and energy efficiency strategies focus on reducing fuel combustion emission as well as utilizing renewable equipment devices and efficient fuel use [45]. Contractors should, therefore, be regulated by the relevant authorities or incentivized to adopt engine retrofit according to technologies verified by the U.S Environmental Protection Agency(EPA) or California Air Resources Board(CARB) through the use of upgrading and repowering engines or engaging in a better selection of their equipment. Nonetheless, the construction companies may alternatively be required to use other fuels for their equipment with the aim of reducing the equipment idling or employing work zone mobility management.

The third level, which entails the green life cycle strategies, focuses on managing the total life cycle of products and services [30]. The approach aims at addressing a wide range of activities, starting with the problem identification, processing or solution acquisition, to the final disposition of the solution. Also, the third level is engaged in providing a framework for targeting, organizing, analyzing, and managing project-related information and activities towards continuous sustainable improvement along the life cycle of the project [46].

This conducted a Life Cycle Assessment (LCA) of residential streets from the perspective of favouring the human scale and reducing motorized traffic flow, and a cradle to handover approach was adopted [47]. The research highlighted that the non-motorized mobility in a residential street generated lower environmental impacts. Also, the research observed that omitting a detailed analysis in the materials selection for a specific zone of residential streets would occasion significant environmental impacts. Moreover, the research noted that the specific use of materials employed in the construction of the RS was having a great influence on the environmental impacts. As a result, the study suggested that the granite should be limited in configuring and designing RS. The application of LCA in the design phase was considered an important factor that could reduce the environmental impacts generated in the product and construction stages of a residential street.

Above all, the fourth level, the clean energy development strategy, focuses on the innovative thinking through infrastructure design, project partnership, construction approaches, financing techniques, methodologies for evaluation, future maintenance, and delivery processes [44]. Although the clean energy development approach is in an early stage for highway construction, successful cases, particularly in the electricity generation and agriculture sectors, have been witnessed where stakeholders can borrow ideas relating to the implementation process and technologies.

\subsection{The Determinants of Quality Standards for Highway Engineering Projects}

Previous research work has highlighted numerous determinants of quality standards for highway engineering projects. The most effective factors influencing the quality standards of highway engineering projects are the adoption of green construction, financial issues, design codes and standards, materials and equipment, human resources, coordination, planning and scheduling, and risks [46]. Research work with respect to materials and equipment observed that these two kinds of construction elements are essential in the operations in every industry since insufficient provision of any of the two can lead to delays in the construction work. To be specific, analysis showed that material organization was an issue of stress in the advancement of any project where $40 \%$ of the delays were credited to repulsive organization, non-attendance of materials when needed, poor unmistakable confirmation of materials and lack of stock-pilling [46]. Financial issues in highway engineering projects has also been an area of focus by many authors. Funding of development projects is subsequently anticipated that would be speculative in monetary terms [13]. In other research, the cost characteristic of materials needed for construction incorporated between $20 \%$ and $50 \%$ of the total project cost and hence, the quality of the projects was more than half dependent on financial 
issues [13]. Other factors found to have some influence on the quality of engineering projects included stakeholders' involvement and competence of the managers.

\section{Methodology}

The research methodology section was important as it described the specific procedures used by the researcher to identify, select, process and analyze the data about green construction management and the quality of highway engineering projects. The section was even more important as it allowed readers to critically evaluate the study's overall validity and reliability. The major sub-sections discussed in the research methodology included research method, research design, population and sample, data collection, quantitative data analysis, qualitative data analysis, ethical consideration, reliability test and validation process.

\subsection{Research Method}

The study adopted a mixed research method where both quantitative and qualitative approaches were mixed in a single study. The quantitative research method involved a research process where numerical data was gathered, analyzed using statistical techniques and conclusions drawn from the analysis results [48]. On the other hand, a qualitative approach allowed the researcher to gather qualitative data, observe trends depicted by these trends and make critical judgements based on the characteristics of the observed trends. Quantitative research emphasizes objective measurements and the statistical or mathematical analysis of the data. In other situations, the quantitative research method was used to manipulate pre-existing statistical data using computational approaches [49].

Adopting the mixed method is justified. This is because the mixed approach was found to have significant advantages over the use of qualitative and mixed methods individually which were the possible alternatives [48]. First, mixed method research is believed to have strengths that offset the weaknesses of both quantitative and qualitative research methods when used individually. Also, mixed research method was advantageous because it provided useful findings regardless of the results being unexpected prior to the research since qualitative data was, to some degree, generalized [50].

\subsection{Research Design}

The study employed a sequential research design. The design presents a scientific method characterized by first collecting and analyzing quantitative data then collecting and analyzing qualitative data later [51]. The two kinds of data were gathered using questionnaires. This research design serves a major purpose of using qualitative results to assist in explaining and interpreting the findings of the quantitative analysis section.

\subsection{Population and Sample}

The study targeted a population of all engineers who worked at construction companies dealing with highway engineering projects. Since the researcher's professional was project management, an engineer was contracted to help in interpreting the engineering terms provided by the study respondents. The population was large and extensive making it impossible for the researcher to gather data from each member of the population. Hence, a sample survey technique was adopted. A sample survey is a study designed to obtain data from a subset of a population with the aim of estimating the population parameters.

The sample population used in the study is randomly sourced. In essence, the use of random sampling seeks to reduce the amount of bias from using a similar sample population. Additionally, random sampling reduces the possibility of choreographed responses within the responses offered. There are a total of 200 respondents that participated in the study. The participants are contacted and respond to the questions posed using an online platform. The respondents are sourced from different groups of employees ranging from the self-employed to those working either in the public or private sector in the economy. 


\subsection{Data Collection}

The study used questionnaires with both closed and open-ended questions to gather data from the sampled individuals. A questionnaire is a research instrument that consists of a series of questions for the purpose of gathering information from respondents [51]. This data collection method was chosen because it enabled the researcher to collect data from a large sample of up to 200 respondents in an easy and economical way. The questionnaire was standardized allowing the respondents to give quantifiable answers for the topic. The open-ended questions were important as they provided information necessary for improving the qualitative aspect of the study.

The survey questionnaire used in the study was matched to capture the specific sets of information needed to answer the research questions. The first section of the questionnaire captures the demographic profile of the respondents. The demographic variables included the respondents' gender, age, and work experience. The second section of the questionnaire looked at green construction management in its general pretext as well as the major determinants of the quality standards for highway engineering projects. This section presented the study's independent variables category. The adoption of the green construction management variable was measured using a categorical scale with values 1 and 2 for those whose companies did not use green construction management and those that used it, respectively. Other variables under independent variables list included financial issues, design codes and standards, materials and equipment, human resources, coordination, planning and scheduling, and risks [52].

The third section of the questionnaire looked at the quality of the highway engineering projects. This section presented the study's dependent variables section. The significant variable under this section was quality which was measured using an ordinal scale ranging from 1-5 for low and high quality respectively. The values were reached based on the quality assurance agencies and the relevant authorities' reports for the assessed projects. The last section of the assessment gives the respondents the opportunity to offer solutions and recommendations based on the implications and recommendations for future highway projects.

The researchers relied on modern statistical tools to record, store and analyze the collected data. Particularly, the researchers used Statistical Package for the Social Sciences (SPSS) software version 20 to analyze the data.

\subsection{Quantitative Data Analysis}

The first research question, regarding the way green construction management affected highway engineering projects, was answered using correlational analysis approach. Correlation analysis attempted to reveal the mutual relationship or connection between the dependent and independent variables [53]. The study used Pearson's correlation coefficient to reveal the correlation between two variables. For any pair of variables $(\mathrm{X}, \mathrm{Y})$, the formula for the Pearson's correlation coefficient, as described by Koo, and Li [54], was as shown below

$$
\rho_{x, y}=\frac{\operatorname{Cov}(X, Y)}{\rho_{x} \rho_{y}}
$$

where:

$\operatorname{Cov}(X, Y)$, was the covariance of $X$ and $Y$.

$\rho_{x}$, was the standard deviation of $X$.

$\rho_{y}$, was the standard deviation of $Y$.

The second research question, regarding the determinants of the quality standards for highway engineering projects, was answered using the multivariate regression analysis technique. Under this analysis section, the researchers were concerned with testing the individual effects of eight factors namely the adoption of green construction management, financial issues, design codes and standards, 
materials and equipment, human resources, coordination, planning and scheduling, and risks. The study adopted the following model [55].

$$
y=\beta_{0}+\beta_{1} x_{1}+\beta_{2} x_{2}+\beta_{3} x_{3}+\beta_{4} x_{4}+\beta_{5} x_{5}+\beta_{6} x_{6}+\beta_{7} x_{7}+\beta_{8} x_{8}+\varepsilon
$$

where: $y$ was the quality of highway engineering projects, while $x_{1}, x_{2}, \ldots, x_{8}$ represented the adoption of green construction management, financial issues, design codes and standards, materials and equipment, human resources, coordination, planning and scheduling, and risks respectively.

The third research question, regarding the significance or the extent to which green construction management improved highway engineering projects, was answered using the T-test analysis technique. Students t-test is a statistical test used to compare the mean of two groups of samples [56]. The study compared the quality of highway engineering projects between the group of respondents whose companies did not adopt green construction management and those that did. The independent t-test formula adopted, as described by Silverman [56], was as shown below.

$$
t=\frac{\bar{x}_{1}-\bar{x}_{2}}{\sqrt{\frac{s^{2}}{n_{1}}+\frac{s^{2}}{n_{2}}}}
$$

where:

$s^{2}$ was an estimator of the common variance of the two samples.

$\bar{x}_{1}$ was the mean of the group of respondents from companies that did not use green construction $\bar{x}_{2}$ was the mean of the group of respondents from the companies that used green construction. $n_{1}$ and $n_{2}$ were the sizes of the two groups respectively.

\subsection{Qualitative Data Analysis}

The qualitative data gathered and finalized through questionnaires and expert discussions was analyzed using factor analysis with the aim of producing mean index and factor loading. Also, the study conducted content analysis of the qualitative data to categorize verbal and behavioral data with the aim of classifying, summarizing and tabulating the data. Furthermore, reformulation of the stories presented by experts through a narrative analysis technique was done where the context of each case as well as different experiences with the green construction management were taken into account.

The figures below show the analysis process for descriptive statistics, the description of bivariate correlation analysis, and the description of the regression analysis process using SPSS (Figures 2-4).

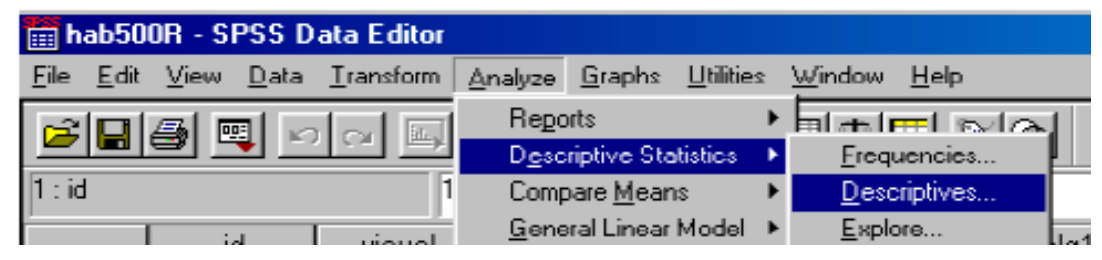

Figure 2. Description of the descriptive analysis using Statistical Package for the Social Sciences (SPSS).

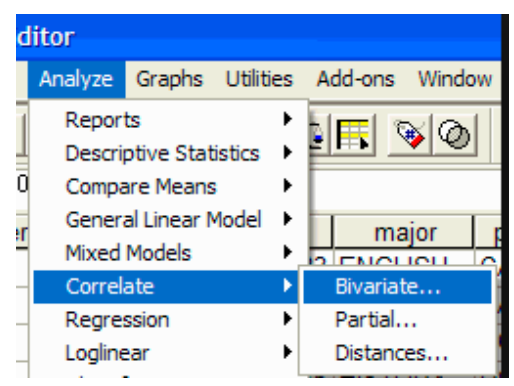

Figure 3. Description of the correlational analysis using SPSS. 


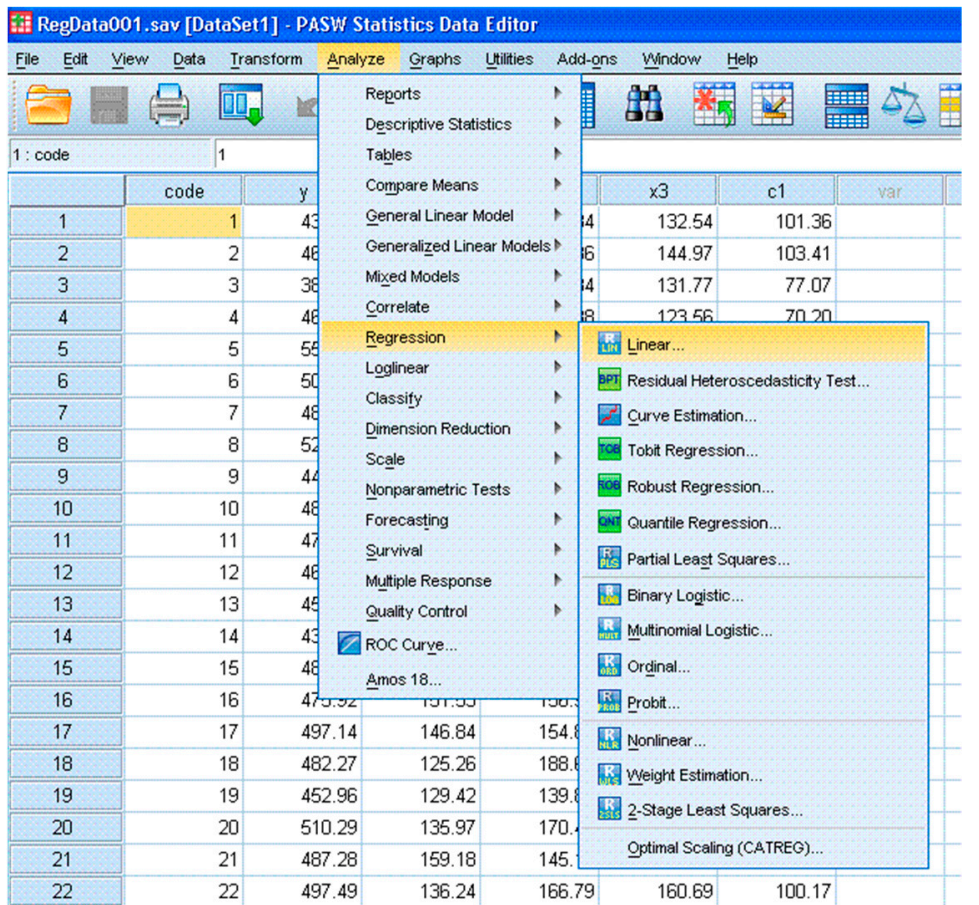

Figure 4. Description of the regression analysis using SPSS.

\subsection{Ethical Considerations}

All the necessary norms and standards for conduct that distinguishes between right and wrong were considered. First, the researcher obtained informed consent from all the participants. Informed consent was taken to show that all the participants took part in the study willingly and free from coercion. Informed consent was obtained using an informed consent form which was sent to the participants via email before participating in the actual study [49]. The other significant ethical consideration was confidentiality and anonymity of the participants' personal data. The researcher employed a number of methods to keep the participants' identity confidential. First, the records were highly secured through the use of password protected files. Second, the information was not recorded in a way that could link participants identifying information with their responses. On the other hand, anonymity was ensured by maintaining the identity of participants unknown to the researcher [51].

\subsection{Reliability Test}

A reliability test was conducted to assess the degree to which the adopted assessment tools produced stable and consistent results. The study adopted an internal consistency reliability test approach. This is a measure of reliability used by researchers to evaluate the degree to which different test items probing the same construct produce similar results.

The reliability test for the questionnaire was done using Cronbach's alpha which assessed the internal consistency. This test was applied to all variables that used the Likert scales in attempt to assess whether the scales were reliable. The analysis obtained a Cronbach's alpha of 0.672 indicating that the alpha coefficient was good. Hence, the test implied that adopted Likert scales in the questionnaire were statistically reliable (Table 1).

Table 1. Reliability test results.

\begin{tabular}{cc}
\hline \multicolumn{2}{c}{ Reliability Statistics } \\
\hline Cronbach's Alpha & N of Items \\
\hline 0.672 & 9 \\
\hline
\end{tabular}




\subsection{Validation Process}

The validation process involved the collection and evaluation of the data, from the process design stage throughout the analysis, in a manner that established scientific evidence that the adopted process was capable of consistently delivering quality products. The current study followed a series of activities throughout the research process to ensure that the whole process was valid. The study adopted a prospective validation approach where documented evidence was established prior to process implementation that a system did what it was supposed to do based on pre-planned protocols. First, the choice of research design was made depending on the research goals and objectives. The researcher then ensured that all the persons involved in various processes such as data collection and data analysis were qualified. Lastly, the researcher ensured that there was a continuous monitoring of the processes to ensure that all the activities were under control.

A further validation of the data using the SPSS was done through the identification of duplicate identifiers (Table 2). The analysis showed that there were 64 and 136 cases without and with duplicate identifiers. A duplicate case represented an entry that was observed more than once in the data set. Since the questionnaire used Likert scale for a majority of the variables, it was expected that a significant number of entries were to be duplicated. Hence, a value of 136 duplicate cases implied that the data was valid.

Table 2. Validation process results.

\begin{tabular}{cccc}
\hline \multirow{2}{*}{$\begin{array}{c}\text { Duplicate Identifiers } \\
\text { Group }\end{array}$} & Number of Duplicates & Cases with Duplicate Identifiers & $\begin{array}{c}\text { Identifier } \\
\text { Construction of Management }\end{array}$ \\
\hline 1 & 64 & $1,2,3,4,5,6,7,8,9,10,11,12,13,14,15,16,17$, & No \\
\hline 2 & \multirow{2}{*}{136} & $65,66,67,68,9,9,70,71,72,73,74,75,76,77,78$, & Yes \\
\hline
\end{tabular}

Notes: For duplicate identifiers groups with more than 25 duplicates, only the first 25 cases are displayed.

\section{Analysis Results and Discussions}

\subsection{Demographic Characteristics of the Sample}

The analysis of the respondents' gender revealed that a majority of the workers in the highway engineering projects are males with a frequency of $130(65.0 \%)$ while females had a frequency of 70 $(35.0 \%)$ (Table 3). The results supported the global findings where literature revealed that women were consistently underrepresented in the engineering and related fields.

Table 3. Gender distribution of the respondents.

\begin{tabular}{ccccc}
\hline & Frequencies & Percentages & Valid Percentages & Cumulative Percent \\
\hline Male & 130 & 65.0 & 65.0 & 65.0 \\
\hline Female & 70 & 35.0 & 35.0 & 100.0 \\
\hline Total & 200 & 100.0 & 100.0 & \\
\hline
\end{tabular}

The respondents had sufficient work experience in the highway engineering work with the majority, $24.5 \%$ (frequency of 49), having an experience of between 5 and 7 years. Other significant proportions had experiences of between 3 and 5 years, and between 7 and 9 years with frequencies equal to $47(23.5 \%)$ and $46(23.0 \%)$ (Table 4$)$. 
Table 4. Frequency distribution for work experience.

\begin{tabular}{ccccc}
\hline & Frequencies & Percentages & Valid Percentages & Cumulative Percent \\
\hline Less than 3 years & 29 & 14.5 & 14.5 & 14.5 \\
\hline Between 3-5 years & 47 & 23.5 & 23.5 & 38 \\
\hline Between 5-7 years & 49 & 24.5 & 24.5 & 62.5 \\
\hline Between 7-9 years & 46 & 23.0 & 23.0 & 85.5 \\
\hline 10 years and above & 29 & 14.5 & 14.5 & 100 \\
\hline Total & 200 & 100.0 & 100.0 & \\
\hline
\end{tabular}

The study, furthermore, made an analysis of the respondents' age to investigate the distribution (Figure 5). Researchers constructed a frequency histogram which produced taller bars around the average age which was 39.13. The shape of the histogram was bell-shaped implying that the distribution of the respondents with respect to their age was normal with a mean of 39.13 and a standard deviation of 8.167 .

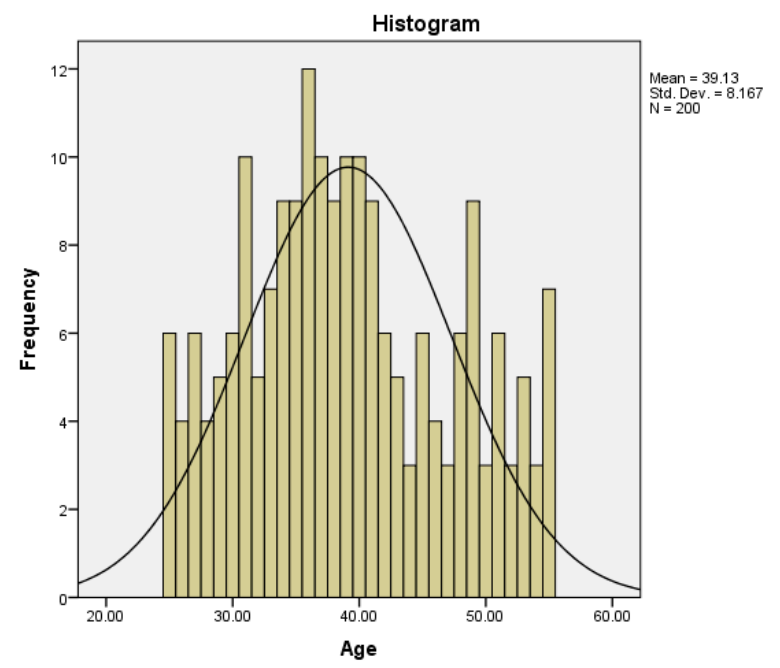

Figure 5. Frequency histogram for the age.

Also, the normality test produced a Shapiro-Wilk statistic equal to 0.967 with a significance value of $0.000<0.05$ (Table 5). Hence the null hypothesis was rejected leading to a conclusion that the sample data was normal.

Table 5. Tests of normality.

\begin{tabular}{ccccccc}
\hline & \multicolumn{3}{c}{ Kolmogorov-Smirnov } & \multicolumn{3}{c}{ Shapiro-Wilk } \\
\hline & Statistic & D f & Sign. & Statistic & D f & Sig. \\
\hline Age & 0.071 & 200 & 0.015 & 0.967 & 200 & 0 \\
\hline
\end{tabular}

The study also conducted a correlation analysis to assess whether there was an association between work experience and age among the sampled individuals (Table 6). According to the analysis, the study produced a Pearson's correlation coefficient equal to 0.101 with a significance value of 0.154 . The correlation coefficient was close to 0 indicating that the association was very weak. Also, the significance value was greater than 0.05 , the set level of significance, implying that the test failed to reject the null hypothesis of no correlation. Hence, a conclusion was made that there was no significant correlation between work experience and respondents' age. 
Table 6. Correlations between work experience and age.

\begin{tabular}{cccc}
\hline \multirow{2}{*}{ Age } & & Age & Work Experience \\
\hline & Pearson Correlation & 1 & 0.101 \\
\cline { 2 - 4 } & Sig. (2-tailed) & & 0.154 \\
\cline { 2 - 4 } Work experience & $\mathrm{N}$ & 200 & 200 \\
\cline { 2 - 4 } & Pearson Correlation & 0.101 & 1 \\
\cline { 2 - 4 } & Sig. (2-tailed) & 0.154 & 200 \\
\hline
\end{tabular}

\subsection{The Effect of Green Construction Management on Highway Engineering}

The relationship between the adoption of green construction management and the quality of highway engineering projects was assessed using Pearson's correlation coefficient as described in the methodology section (Table 7). The analysis yielded a correlation coefficient equal to 0.777 with a probability value equal to $0.000<0.05$. Since the $p$-value was less than 0.05 , the results implied that the test rejected the null hypothesis of independence and led to a conclusion that the adoption of green construction management and the quality of highway engineering projects were significantly correlated. Moreover, the correlation coefficient was positive and close to 1, implying that the relationship was positive and strong. Hence, it was concluded that an increase in the level of adoption of green construction management led to an increase in the quality of the highway engineering projects.

Table 7. Correlation results between the adoption of green construction management and quality of the highway engineering projects.

\begin{tabular}{cccc}
\hline & & $\begin{array}{c}\text { At What Level Was the Green } \\
\text { Construction Adopted? }\end{array}$ & $\begin{array}{c}\text { Quality of the Highway } \\
\text { Engineering Projects }\end{array}$ \\
\hline \multirow{2}{*}{$\begin{array}{c}\text { At what level was the green } \\
\text { construction adopted? }\end{array}$} & Pearson Correlation & 1 & 0.777 \\
\cline { 2 - 4 } & Sign & 200 & 0 \\
\hline \multirow{2}{*}{$\begin{array}{c}\text { Quality of the highway } \\
\text { engineering projects }\end{array}$} & $\mathrm{N}$ & 0.777 & 200 \\
\cline { 2 - 4 } & Pearson Correlation & 0 & 1 \\
\cline { 2 - 4 } & $\mathrm{Sign}$ & 200 & 200 \\
\hline
\end{tabular}

The above findings are similar to the findings in the previous research work. Adoption of green construction management leads to improvement in quality of the projects [57]. The information available in the literature showed that the impact of green construction management in the highway engineering projects can be witnessed in the management of roads, parking and other facilities. In modern highway design, new technologies such as intelligent construction, advanced planning, and transport systems as well as maintenance techniques have been found to minimize the impact highways have to the environment [58].

The analysis of the green performance contracting strategies data revealed that the most effective strategy was material related with a frequency of $82(41.0 \%)$ followed by equipment and energy efficient strategies with a frequency of $68(34.0 \%)$. Other strategies highlighted by the study included the green life cycle and clean energy development strategies with frequencies equal to $33(16.5 \%)$ and $17(8.5 \%)$ respectively (Table 8$)$. 
Table 8. Frequency distribution for green performance contracting (GPC) strategies.

\begin{tabular}{ccccc}
\hline & Frequencies & Percentages & Valid Percentages & Cumulative Percent \\
\hline Material Related Strategies & 82 & 41 & 41 & 41 \\
\hline Equipment and energy efficient strategies & 68 & 34 & 34 & 75 \\
\hline Green life cycle strategies & 33 & 16.5 & 16.5 & 91.5 \\
\hline Clean Energy development strategies & 17 & 8.5 & 8.5 & 100 \\
\hline
\end{tabular}

\subsection{The Determinants of the Quality Standards for Highway Engineering Projects}

The study assessed the level of influence of eight possible determinants of quality standards for highway engineering projects namely the adoption of green construction management, financial issues, design codes and standards, materials and equipment, human resources, coordination, planning and scheduling, and risks. These factors were highlighted by the previous researchers, as revealed in the literature, as having notable effects on the quality standards for highway engineering projects [52]. A linear regression model was fitted to the data gathered. The analysis yielded a computed R-value equal to 0.880 and $\mathrm{R}$-squared value of 0.775 . The $\mathrm{R}$-value represented the coefficient of correlation and it implied that the eight determinants of quality standards for highway engineering projects were strongly correlated with the quality of highway engineering projects. On the other hand, the $\mathrm{R}$-squared value represented the coefficient of multiple determination. The value suggested that the adoption of green construction management, financial issues, design codes and standards, materials and equipment, human resources, coordination, planning and scheduling, and risks explained $77.5 \%$ of the variations in the quality of the highway engineering projects (Table 9).

Table 9. Summary results for the regression model.

\begin{tabular}{ccccc}
\hline Models & R-Value & R-Squared & Adjusted R-Squared & Standard Error \\
\hline 1 & 0.880 & 0.775 & 0.766 & 1.02221 \\
\hline
\end{tabular}

The joint effect of the factors on the quality of the highway engineering projects was revealed using an analysis of variance (ANOVA) (Table 10). According to the analysis, the computed value of F-statistic was equal to 82.354 with a p-value of $0.000<0.05$. Since the $p$-value was less than 0.05 , the test rejected the null hypothesis which stated that the joint effect was insignificant. Hence, a conclusion was made that the joint effect of the adoption of green construction, financial issues, design codes and standards, materials and equipment, human resources, coordination, planning and scheduling, and risks on the quality of the highway engineering projects was significant.

Table 10. Analysis of variance (ANOVA) results.

\begin{tabular}{cccccc}
\hline Models & Sum of Sqs. & df & Mean Sq. & F-Value & Sig. \\
\hline Reg. & 688.422 & 8 & 86.053 & 82.354 & $0.000^{\text {a }}$ \\
\hline Res. & 199.578 & 191 & 1.045 & & \\
\hline Total & 888.000 & 199 & & & \\
\hline
\end{tabular}

Note: Dependent Variable: quality of the highway engineering projects. ${ }^{\text {a }}$ Predictors: (Constant), risks, planning and scheduling, At what level was the green construction adopted, human resources, design codes and standards, materials and equipment, Financial issues, coordination.

The individual effects of the adoption of green construction management, financial issues, design codes and standards, materials and equipment, human resources, coordination, planning and scheduling, and risks on the quality of the highway engineering projects were assessed using the results of the regression model's coefficients (Table 11) [46,52]. The independent factors were selected based on the results of the factor analysis. These factors were found to have the most significant effects on the dependent variable. 
From the analysis, the coefficients were equal to $4.582,0.246,-0.380,0.363,0.178,0.176,-0.014$, 0.146 , and -0.449 for the constant, adoption of green construction management, financial issues, design codes and standards, materials and equipment, human resources, coordination, planning and scheduling, and risks respectively. The coefficients suggested that the equation representing the fitted model was of the form shown below.

$$
y=4.582+0.246 x_{1}-0.38 x_{2}+0.363 x_{3}+0.178 x_{4}+0.176 x_{5}-0.014 x_{6}+0.146 x_{7}-0.449 x_{8}
$$

where:

$y$ was the quality of highway engineering projects, while $x_{1}, x_{2}, \ldots, \mathrm{x}_{8}$ represented the adoption of green construction management, financial issues, design codes and standards, materials and equipment, human resources, coordination, planning and scheduling, and risks respectively.

The significance of these determinants of quality standards for the highway engineering projects was assessed using t-statistics together with their associated probability values. The factors which yielded significant results included the adoption of the green construction, financial issues, design codes and standards, and various risks with $t$-values and respective $p$-values equal to 2.881 (p-value $=0.004),-2.928(\mathrm{p}$-value $=0.004), 2.516(\mathrm{p}$-value $=0.013)$, and $-3.575(\mathrm{p}$-value $=0.000)$ respectively (Table 9).

From the analysis, it was revealed that different factors affected the quality standards of the engineering projects differently. Adoption of green construction management, design codes and standards, material and equipment, human resources and planning and scheduling affected the quality of engineering projects positively. Conversely, financial issues, coordination, and risks affected the quality of the engineering projects negatively.

Table 11. Coefficient results between the model parameters and effectiveness.

\begin{tabular}{cccccc}
\hline \multirow{2}{*}{ Model } & \multicolumn{2}{c}{ Unstandardized } & Standardized & \multirow{2}{*}{ t-stat } & \multirow{2}{*}{ Sign. } \\
\cline { 2 - 5 } & $\mathbf{B}$ & Standard Error & Beta & & \\
\hline $\begin{array}{c}\text { (Constant/intercept) } \\
\begin{array}{c}\text { At what level was the green } \\
\text { construction management adopted }\end{array}\end{array}$ & 0.582 & 0.786 & & 5.827 & 0.000 \\
\hline Financial issues & -0.380 & 0.130 & -0.199 & -2.928 & 0.004 \\
\hline design codes and standards & 0.363 & 0.144 & 0.168 & 2.516 & 0.013 \\
\hline materials and equipment & 0.178 & 0.143 & 0.083 & 1.246 & 0.214 \\
\hline human resources & 0.176 & 0.136 & 0.082 & 1.291 & 0.198 \\
\hline coordination & -0.014 & 0.148 & -0.007 & -0.094 & 0.925 \\
\hline planning and scheduling & 0.146 & 0.139 & 0.069 & 1.051 & 0.295 \\
\hline risks & -0.449 & 0.126 & -0.233 & -3.575 & 0.000 \\
\hline
\end{tabular}

Elements above come from Larsen, J.K. [52].

The findings revealed that there are many determinants of the quality standards for highway engineering projects. The findings are in agreement with findings from other research work conducted in the past. No matter what definition of quality is followed, the term becomes very complex when researchers try to put it into actual practice since there are many factors influencing its variation [59].

These findings were partially in agreement with the information found in the available literature. In addition to the eight factors which were considered as significant influencers of quality standards of highway engineering projects, researchers still identified some other mediating factors. Also, according to the available literature, the study revealed that interest-free lending has an impact on the project bidding process for contractors willing to work with governments. The interest-free ending rates can be used to overcome the market and financial non-profitability rates $[60,61]$. The insistence from clients to assure investment returns is a huge contributor to the incentive to take up green construction 
projects [30]. The green mark certification must be established as a mandatory requirement for all new and repair highway construction projects [62]. The issuance of subsidy schemes shall encourage a greater number of contractors to take up green construction in highway projects [63]. Boosting the public and market demand for green construction highway projects encourages the participation of the public in terms of ameliorating the number of clients interested in green construction. The most effective factors influencing the quality standards of highway engineering projects are the adoption of green construction, financial issues, design codes and standards, materials and equipment, human resources, coordination, planning and scheduling, and risks [46].

\subsection{The Extent to which Green Construction Management Improves the Quality of Highway Engineering Projects}

All the respondents whose companies had recorded some levels of adoption of green construction management were put under one category and the quality of their highway engineering projects compared to that of respondents whose companies had not adopted green construction management. The group statistics produced total observations equal to 64 and 136 for the no and yes groups, respectively (Table 12). The means (and the standard deviations) of the quality of the engineering projects were equal to $3.1719(\mathrm{SD}=1.229)$ and $6.5956(\mathrm{SD}=1.447)$ for the group that did not adopt and that which adopted green construction management, respectively.

Table 12. Quality group statistics.

\begin{tabular}{cccccc}
\hline & $\begin{array}{c}\text { Adoption of Green } \\
\text { Construction }\end{array}$ & Observations & Means & $\begin{array}{c}\text { Std. } \\
\text { Deviations }\end{array}$ & $\begin{array}{c}\text { Standard } \\
\text { Errors }\end{array}$ \\
\hline $\begin{array}{c}\text { Quality of the highway } \\
\text { engineering projects }\end{array}$ & No & 64 & 3.1719 & 1.22869 & 0.15359 \\
\cline { 2 - 6 } & Yes & 136 & 6.5956 & 1.44724 & 0.12410 \\
\hline
\end{tabular}

The significance of the observed difference in the group statistics was assessed using independent samples T-test (Table 13). The computed t-statistic was equal to -16.350 with a probability value of $0.000<0.05$. The probability value was less than 0.05 , suggesting that the test rejected the null hypothesis which stated that the difference was significant. Hence, a conclusion was made that green construction management improved the quality of the engineering projects to a significant extent.

Table 13. Independent samples test.

\begin{tabular}{|c|c|c|c|c|c|c|c|c|c|c|}
\hline \multicolumn{5}{|c|}{ Levene's Test } & \multicolumn{6}{|c|}{ t-Test } \\
\hline & & $\mathbf{F}$ & Sig. & $\mathbf{t}$ & D f & Sign. & $\begin{array}{l}\text { Mean } \\
\text { Diff }\end{array}$ & $\begin{array}{l}\text { Standard. } \\
\text { Error }\end{array}$ & $\mathbf{L}$ & $\mathbf{U}$ \\
\hline \multirow{2}{*}{$\begin{array}{l}\text { Quality of the } \\
\text { highway engineering } \\
\text { projects }\end{array}$} & $\begin{array}{c}\text { Equal } \\
\text { variances }\end{array}$ & 2.084 & 0.150 & -16.4 & 198 & 0.00 & -3.42 & 0.209 & -3.83 & -3.01 \\
\hline & $\begin{array}{c}\text { Non-Equal } \\
\text { variances }\end{array}$ & & & -17.3 & 143.56 & 0.00 & -3.42 & 0.197 & -3.81 & -3.03 \\
\hline
\end{tabular}

\subsection{Factor Analysis}

The table of communalities presented below shows how much of the variance in the variables as accounted for by the extracted factors (Table 14). According to the analysis, the factor with the highest accounted variance was work experience where $91.5 \%$ of its variance was accounted for while risk had the lowest variance accounted for. 
Table 14. Communalities a variance in the variables.

\begin{tabular}{ccc}
\hline & Initial & Extraction \\
\hline Work experience & 1 & 0.915 \\
\hline At what level was the green construction adopted & 1 & 0.77 \\
\hline Financial issues & 1 & 0.537 \\
\hline design codes and standards & 1 & 0.612 \\
\hline materials and equipment & 1 & 0.508 \\
\hline human resources & 1 & 0.456 \\
\hline coordination & 1 & 0.76 \\
\hline planning and scheduling & 1 & 0.514 \\
\hline risks & 1 & 0.55 \\
\hline
\end{tabular}

Note: Extraction Method: Principal Component Analysis. ${ }^{\text {a }}$ Only cases for which quality of the highway engineering projects $=5$ are used in the analysis phase.

The number of extracted factors whose sum equaled the number of items which were subjected to the factor analysis was reflected using the eigenvalues. According to the analysis, the highest total variance as described by the initial eigenvalue was 4.535 where the percentage of variance attributed to this factor was $50.389 \%$. The percentages of variance attributed to each factor after extraction were equal to 50.398 and 12.084 for the first and second components, respectively (Table 15).

Table 15. Total variance explained ${ }^{\mathrm{a}}$.

\begin{tabular}{ccccccc}
\hline \multirow{2}{*}{ Component } & \multicolumn{3}{c}{ Initial Eigenvalues } & \multicolumn{2}{c}{ Extraction Sums of Squared Loadings } \\
\cline { 2 - 7 } & Total & \% of Variance & Cumulative \% & Total & \% of Variance & Cumulative \% \\
\hline 1 & 4.535 & 50.389 & 50.389 & 4.535 & 50.389 & 50.389 \\
\hline 2 & 1.088 & 12.084 & 62.473 & 1.088 & 12.084 & 62.473 \\
\hline 3 & 0.941 & 10.45 & 72.923 & & & \\
\hline 4 & 0.81 & 9 & 81.923 & & \\
\hline 5 & 0.557 & 6.193 & 88.116 & & \\
\hline 6 & 0.379 & 4.213 & 92.329 & & \\
\hline 7 & 0.324 & 3.602 & 95.931 & & \\
\hline 8 & 0.199 & 2.215 & 98.146 & & & \\
\hline 9 & 0.167 & 1.854 & 100 & & & \\
\hline
\end{tabular}

Note: Extraction method: principal component analysis. ${ }^{a}$ Only cases for which quality of the highway engineering projects $=5$ are used in the analysis phase.

The extracted values of each item under the two variables, known as loadings of the 10 variables on the three factors extracted, are presented in the component matrix below (Table 16). The results showed that the contribution of the factors as described by the absolute value of the loading varied significantly. The analysis was conducted to assess whether the assertion in the literature regarding the factors influencing the quality of highway engineering projects. Hence, while the results described in the table below were independently computed, the findings have a relationship with those observed in Table 11. The results supported the assertion in the literature review which led to the adoption of a linear regression model as described in Table 11. According to the assertion, the most effective factors influencing the quality standards of highway engineering projects are the adoption of green construction, financial issues, design codes and standards, materials and equipment, human resources, coordination, planning and scheduling, and risks. The elements in the table below were obtained after the researcher replaced the codes with their respective factors as described in the SPSS variable view. 
Table 16. Component matrix ${ }^{\mathrm{a}, \mathrm{b}}$.

\begin{tabular}{ccc}
\hline & \multicolumn{2}{c}{ Component } \\
\cline { 2 - 3 } & $\mathbf{1}$ & $\mathbf{2}$ \\
\hline Work experience & -0.232 & 0.928 \\
\hline At what level was the green construction adopted & 0.877 & -0.008 \\
\hline Financial issues & -0.714 & 0.163 \\
\hline design codes and standards & 0.772 & 0.126 \\
\hline materials and equipment & 0.672 & -0.238 \\
\hline human resources & 0.601 & 0.308 \\
\hline coordination & 0.866 & 0.104 \\
\hline planning and scheduling & 0.716 & 0.031 \\
\hline risks & -0.728 & -0.144
\end{tabular}

Note: Extraction method: principal component analysis. ${ }^{a} 2$ components extracted. ${ }^{b}$ Only cases for which quality of the highway engineering projects $=5$ are used in the analysis phase.

\subsection{Analysis of the Challenges of Green construction project}

The analysis of the qualitative data revealed that numerous challenges are facing green construction projects. Among the many challenges was the higher costs for green construction practices and materials. Unlike conventional projects, green construction projects cost more during construction. A previous study estimated the capital costs for green construction projects as within a range of $1 \%-25 \%$ higher than the conventional projects. The higher costs were associated with the complexity of the designs as well as the modelling costs needed to integrate green practices into projects.

Another challenge highlighted by the qualitative analysis was the technical difficulty experienced during the construction process. In most cases, green technologies call for complicated techniques as well as construction processes. Failure to address such complexities leads to poor performance. Also, complications within the design are tougher in a green construction project than they are in a conventional project.

Other significant challenges may include risks due to different contract forms of project delivery, approval processes being too long for new green technologies as well as recycled materials, and lack of familiarization with green technologies.

The long-term impacts of green construction offer formidable solutions to promoting sustainability for future generations [64]. The evidence in the study indicates that there is a difference in the quality of highway engineering projects based on the costs incurred promoting green construction. There is a common challenge faced by project managers when it comes to ensuring the new highway projects meet the green construction expectations [65]. The literature review carried by this study reveals that there are various challenges faced by contractors and project managers in their effort to promote green construction in highways. As noted above, green construction increases the cost of production.

\section{Conclusion and Recommendations}

\subsection{Conclusion}

The study, through the data analysis and discussion presented in the previous section, was able to achieve the set objectives. The first objective was to investigate the most effective green performance constructing strategies. The outcome with respect to this objective suggested for strategies that would thoroughly focus on financial issues, design codes and standards, and various risks. The second objective was to assess the determinants of the quality standards for highway engineering projects. The study highlighted eight determinants. The outcome regarding this objective revealed that the adoption of green construction, financial issues, design codes and standards, materials and equipment, 
human resources, coordination, planning and scheduling, and risks explained $77.5 \%$ of the variations in the quality of the highway engineering projects. The third objective was to investigate the extent to which green construction management improve highway engineering projects. The results obtained with respect to this objective suggested that the quality of highway engineering projects was expected to improve by 0.246 units for a unit change in the adoption of green construction.

The study revealed that the adoption of green construction management and the quality of highway engineering projects were significantly correlated with a correlation coefficient of 0.777 . Hence, it was concluded that an increase in the level of adoption of green construction management led to an increase in the quality of the highway engineering projects. Material related and equipment and energy efficiency green performance contracting strategies were considered the most effective strategies for improving the impact of green construction management on the quality of highway engineering projects.

Also, when jointly assessed, the determinants of the quality standards for highway engineering projects had significant effects. However, when assessed individually, different factors were found to affect the quality standards of the highway engineering projects differently. The factors which yielded significant results included the adoption of green construction management, financial issues, design codes and standards, and various risks. Furthermore, the adoption of green construction management, design codes and standards, material and equipment, human resources and planning and scheduling affected the quality of engineering projects positively. Conversely, financial issues, coordination, and risks affected the quality of the engineering projects negatively. According to the available literature, the study revealed that interest-free lending has an impact on the project bidding process for contractors willing to work with the governments. The interest-free ending rates can be used to overcome the market and financial non-profitability rates. The insistence of clients to assure investment returns is a huge contributor to the incentive to take up green construction projects. The green mark certification must be established as a mandatory requirement for all new and repair highway construction projects.

Furthermore, according to the analysis, the group of respondents who used green construction management produced significantly higher mean quality levels for the highway engineering projects than the group that did not apply green construction management. The aforementioned strategies are crucial in reducing the high implementation cost of green practices. The issuance of subsidy schemes shall encourage a greater number of contractors to take up green construction management in highway projects. Boosting the public and market demand for green construction highway projects encourages the participation of the public in terms of ameliorating the number of clients interested in green construction management.

The long-term impacts of green construction projects offer formidable solutions to promoting sustainability for future generations. The evidence in the study indicates that there is a difference in the quality of highway engineering projects based on the costs incurred promoting green construction management. There is a common challenge faced by project managers when it comes to ensuring the new highway projects meet green construction project expectations. The literature review carried out by this study reveals that there are various challenges faced by contractors and project managers in their effort to promote green construction in highways. As noted above, green construction management increases the cost of production.

\subsection{Recommendations}

Stakeholders in the highway engineering projects are recommended to use green construction management so as to improve the quality of their projects. However, recommendations over the use of green construction management of highway construction projects require an adjustment in the budget and the scheduling depending on the level of innovation involved. The use of green construction techniques requires high implementation strategies and thus increases the time and scheduling processes incorporated in the design and realization process. To start with, it is 
important that the timing and the scheduling process in green construction management are treated with utmost specificity as compared to other forms of highway construction. The use of green construction in highway engineering projects decreases the number of new clients bidding for highway construction jobs.

Second, green construction management requires collaborative efforts among all members of the team [66]. The lack of credible research regarding this issue limits the interaction among the team members this making it difficult for the managers of green construction projects [67].

Third, it is recommendable that the contractors are not discouraged from using green construction management as it involves higher scheduling targets and heightened budgets. The introduction of green construction management techniques has been rejected as compared to the reception offered to traditional construction techniques.

Fourth, integrating the research findings from empirical and theoretical evidence with actual evidence on the ground, aids in developing much more sustainable projects for future generations. Evidently, a much stricter environmental assessment is to be done to single out green construction and this is thus more likely to offer alternatives on alleviating the negative impacts of green construction.

With regards to the shortcomings of the study and the direction in which it can continue to study in the future, it is advisable that the scale of analysis is expanded to account for the difference in the level of development across different societies. In essence, a great proportion of green construction projects on highways is conducted in societies that are already developed. Developed countries are more equipped with high technology and high innovation indices that are necessary for green construction project in highway projects.

Another shortcoming in this study is its limitation to the green construction management as opposed to offering a comparative standpoint against conventional construction projects. A comparative analysis requires much more input. However, the aforementioned analysis requires much time and resources. It is imperative that future projects regarding the issue account for the evident comparative differences.

Author Contributions: X.W. designed this study, collected and organized the relevant data, drafted the manuscript; W.Z. designed the research framework and made some suggestions for the first manuscript; T.M. made some suggestions for the first manuscript. All authors read and approved the final manuscript.

Funding: This research was funded by Hainan Provincial Transportation Science and Technology Project, grant number JT20170898006.

Conflicts of Interest: The authors declare no conflict.

\section{References}

1. Alias, A.; Isa, N.K.M.; Samad, Z.A. Sustainable building through project planning process. Eur. J. Sustain. Dev. 2014, 3, 207-218. [CrossRef]

2. Hwang, B.G.; Tan, J.S. Sustainable project management for green construction: Challenges, impact and solutions. In Proceedings of the World Construction Conference 2012-Global Challenges in Construction Industry, Colombo, Sri Lanka, 28-30 June 2012.

3. Zhang, J. Delivering Environmentally Sustainable Economic Growth: The Case of China; Asia Society Report; University of California: San Diego, CA, USA, 2012; pp. 2-25.

4. Wu, C.; Barnes, D. An integrated model for green partner selection and supply chain construction. J. Clean . Prod. 2016, 112, 2114-2132. [CrossRef]

5. Attahiru, Y.B.; Aziz, M.M.A.; Kassim, K.A.; Shahid, S.; Bakar, W.A.W.A.; NSashruddin, T.F.; Ahamed, M.I. A review on green economy and development of green roads and highways using carbon neutral materials. Renew. Sustain. Energy Rev. 2019, 101, 600-613. [CrossRef]

6. Giordan, D.; Thuro, K.; Wu, F.; Delgado, C.; Lollino, G.; Carranza-Torres, C.; Marinos, P. Volume 6: Applied Geology for Major Engineering Projects. In Engineering Geology for Society and Territory; Springer: Berlin/Heidelberg, Germany, 2015. 
7. Amiril, A.; Nawawi, A.H.; Takim, R.; Latif, S.N.F.A. Transportation infrastructure project sustainability factors and performance. Procedia-Soc. Behav. Sci. 2014, 153, 90-98. [CrossRef]

8. Al-Yami, A.M.; Price, A.D. A framework for implementing sustainable construction in building briefing project. Assoc. Res. Constr. Manag. 2006, 1, 327-337.

9. Bujang, M.; Hainin, M.R.; Majid, M.Z.A.; Satar, M.K.I.M.; Azahar, W.N.A.W. Assessment framework for pavement material and technology elements in green highway index. J. Clean. Prod. 2018, 174, 1240-1246. [CrossRef]

10. Sun, W.; Lu, G.; Ye, C.; Chen, S.; Hou, Y.; Wang, D.; Oeser, M. The state of the art: Application of green technology in sustainable pavement. Adv. Mater. Sci. Eng. 2018, 2018, 1-19. [CrossRef]

11. Balubaid, S.; Bujang, M.; Aifa, W.N.; Seng, F.K.; Rooshdi, R.R.R.M.; Hamzah, N.; Hainin, M.R. Assessment index tool for green highway in Malaysia. J. Teknol. 2015, 77, 99-104. [CrossRef]

12. Mell, I.; Allin, S.; Reimer, M.; Wilker, J. Strategic green infrastructure planning in Germany and the UK: A transnational evaluation of the evolution of urban greening policy and practice. Int. Plan. Stud. 2017, 22, 333-349. [CrossRef]

13. Lee, E.M.; Fookes, P.G. A note on the origins of engineering geomorphology in the UK. Q. J. Eng. Geol. Hydrogeol. 2015, 48, 147-156. [CrossRef]

14. Attia, S.; Hensen, J.L.; Beltrán, L.; De Herde, A. Selection criteria for building performance simulation tools: Contrasting architects' and engineers' needs. J. Build. Perform. Simul. 2012, 5, 155-169. [CrossRef]

15. Darko, A.; Chan, A.P. Critical analysis of green building research trend in construction journals. Habit. Int. 2016, 57, 53-63. [CrossRef]

16. Cole, L. The green building as a medium for environmental education. Mich. J. Sustain. Fall 2013, 1, 161-169. [CrossRef]

17. Zhu, X.; Cui, Q.; Gevorg Avetisyan, H. Green Performance Contracting Strategy for Highway Construction Projects. Organ. Technol. Manag. Constr. 2014, 6, 1122-1133. [CrossRef]

18. Eisenberg, D.; Done, R.; Ishida, L. Breaking down the Barriers: Challenges and Solutions to Code Approval of Green Building; Development Center for Appropriate Technology: Tucson, AZ, USA, 2002.

19. Du Plessis, C. A strategic framework for sustainable construction in developing countries. Constr. Manag. Econ. 2007, 25, 67-76. [CrossRef]

20. Zhang, X.; Shen, L.; Wu, Y.; Qi, G. Barriers to implement green strategy in the process of developing real estate projects. Open Waste Manag. J. 2011, 4, 33-37.

21. Garman, J.; Bowyer, J.; Bratkovich, S.; Frank, M.; Fernholz, K.; Howe, J. Building Codes: Barriers to Green Innovation; Dovetail Partners: Littleton, MA, USA, 2011.

22. Garbarino, E.; Quintero, R.R.; Donatello, S.; Oliver, W. Revision of Green Public Procurement Criteria for Road Design, Construction and Maintenance; Technical Report; Publications Office of the European Union: Luxembourg, 2016.

23. World Economic Forum. Shaping the Future of Construction a Breakthrough in Mindset and Technology; World Economic Forum: Cologny, Switzerland, 2016.

24. Wilson, J.L.; Tagaza, E. Green buildings in Australia: Drivers and barriers. Aust. J. Struct. Eng. 2006, 7, 57-63. [CrossRef]

25. Uher, T.E.; Lawson, W. Sustainable development in construction. In Proceedings of the 14th CIB World Building Congress on Construction and the Environment, Gävle, Sweden, 7-12 June 1998; Volume 7, pp. 7-12.

26. Tomkiewicz, H.S. Barriers to Implementation of Sustainable Construction Practices in the Homebuilding Industry: A Case Study of Rochester, NY. Ph.D. Thesis, University of Nebraska, Lincoln, NE, USA, 2011.

27. Delnavaz, M. Project Managers' Role in Sustainable Building Process. Master's Thesis, Chalmers University of Technology, Göteborg, Sweden, 15 May 2012.

28. Goh, K.C.; Yang, J. Responding to sustainability challenge and cost implications in highway construction projects. In Proceedings of the Full Paper Proceedings-CIB 2010 World Congress, Lowty, Salford Quays, UK, 10-13 May 2010.

29. Road Maintenance: Options for Reforms. Building Australia Together; Infrastructure Partnerships Australia: Sydney, NSW, Australia, 2011.

30. Kibert, C.J. Sustainable Construction: Green Building Design and Delivery; John Wiley \& Sons: Hoboken, NJ, USA, 2016. 
31. Ahmad, T.; Aibinu, A.; Stephan, A. Green Building Projects: Process Innovation Leading to Project Innovation. In Proceedings of the 33rd Annual ARCOM Conference, Cambridge, UK, 4-6 September 2017.

32. Gupta, H.; Barua, M.K. Supplier selection among SMEs on the basis of their green innovation ability using BWM and fuzzy TOPSIS. J. Clean. Prod. 2017, 152, 242-258. [CrossRef]

33. Sims, M.; Center, E.E.; Meier, A. An Examination of the Recertification Processes of Building Certification Systems. In Proceedings of the 2012 ACEEE Summer Study on Energy Efficiency in Buildings, Pacific Grove, CA, USA, 12-17 August 2012; Volume 3, pp. 340-349.

34. Shane, J.; Strong, K.; Gransberg, D.; Jeong, D. Guide to Project Management Strategies for Complex Projects; National Academies of Science: Washhington, DC, USA, 2015.

35. Kokkaew, N.; Rudjanakanoknad, J. Green assessment of Thailand's highway infrastructure: A Green Growth Index approach. KSCE J. Civ. Eng. 2017, 21, 2526-2537. [CrossRef]

36. Sang, P.; Liu, J.; Zhang, L.; Zheng, L.; Yao, H.; Wang, Y. Effects of Project Manager Competency on Green Construction Performance: The Chinese Context. Sustainability 2018, 10, 3406. [CrossRef]

37. Hwang, B.G.; Ng, W.J. Are Project Managers Ready for Green Construction?- Challenges, Knowledge Areas, and Skills. In Proceedings of the CIB World Building Congress 2013, St. Lucia, Australia, 5-9 May 2013.

38. Hwang, B.G.; Tan, J.S. Green building project management: Obstacles and solutions for sustainable development. Sustain. Dev. 2012, 20, 335-349. [CrossRef]

39. Gunathilake, S.V.; Liyanage, C.L. Harmonizing sustainable construction policy with practice at project level. In Proceedings of the 26th Annual Conference of the Association of Researchers in Construction Management (ARCOM), Leeds, UK, 6-8 September 2010.

40. Gündoğan, H. Motivators and Barriers for Green Building Construction Market in Turkey. Ph.D. Thesis, Civil Engineering Middle East Technical University, Ankara, Turkey, 2012.

41. Hill, R.C.; Bergman, J.G.; Bowen, P.A. A framework for the attainment of sustainable construction. In Proceedings of the First International Conference on Sustainable Construction, Tampa, FL, USA, 6-9 November 1994; Volume 16, pp. 6-9.

42. Hasan, M.S.; Zhang, R.J. Critical barriers and challenges in implementation of green construction in China. Int. J. Curr. Eng. Technol. 2016, 6, 435-445.

43. Gunawansa, A.; Kua, H.W. Lessons on climate change mitigation and adaptation Strategies for the construction industry from three coastal cities. In Proceedings of the RICS COBRA Research Conference, Cape Town, South Africa, 10-11 September 2009.

44. Song, X.; Wang, T.; Nie, T.; Guo, X. Green Performance Bond: Managing Greenhouse Gas (GHG) Emissions in Construction Projects. J. Eng. Archit. 2016, 4, 1-16.

45. Nusa, F.N.M.; Nasir, S.; Endut, I.R. Awareness of Green Highway Concept and Terminology: A Perspective of On-Site Personnel in Malaysian Highway Construction Industry. Adv. Transp. Logist. Res. 2018, 1, 475-487.

46. Hwang, B.G.; Zhao, X.; Tan, L.L.G. Green building projects: Schedule performance, influential factors and solutions. Eng. Constr. Arch. Manag. 2015, 22, 327-346. [CrossRef]

47. Gámez-García, D.C.; Saldaña-Márquez, H.; Gómez-Soberón, J.M.; Corral-Higuera, R.; Arredondo-Rea, S.P. Life Cycle Assessment of residential streets from the perspective of favoring the human scale and reducing motorized traffic flow. From cradle to handover approach. Sustain. Cities Soc. 2019, 44, 332-342. [CrossRef]

48. Creswell, J.W.; Creswell, J.D. Research Design: Qualitative, Quantitative, and Mixed Methods Approaches; Sage Publications: Thousand Oaks, CA, USA, 2017.

49. Smith, J.A. (Ed.) Qualitative Psychology: A Practical Guide to Research Methods; Sage: Thousand Oaks, CA, USA, 2015.

50. Bell, E.; Bryman, A.; Harley, B. Business Research Methods; Oxford University Press: Oxford, UK, 2018.

51. Quinlan, C.; Babin, B.; Carr, J.; Griffin, M. Business Research Methods, 2nd ed.; South Western Cengage: Andover, UK, 2019; ISBN 9781473760356.

52. Larsen, J.K.; Shen, G.Q.; Lindhard, S.M.; Brunoe, T.D. Factors affecting schedule delay, cost overrun, and quality level in public construction projects. J. Manag. Eng. 2015, 32, 04015032. [CrossRef]

53. Chatfield, C. Introduction to Multivariate Analysis; Routledge: Abingdon-on-Thames, UK, 2018.

54. Koo, T.K.; Li, M.Y. A guideline of selecting and reporting intraclass correlation coefficients for reliability research. J. Chiropr. Med. 2016, 15, 155-163. [CrossRef] [PubMed]

55. Husson, F.; Lê, S.; Pagès, J. Exploratory Multivariate Analysis by Example Using R; Chapman and Hall/CRC: Boca Raton, FL, USA, 2017. 
56. Silverman, B.W. Density Estimation for Statistics and Data Analysis; Routledge: Abingdon-on-Thames, UK, 2018.

57. Tezel, A.; Koskela, L.; Aziz, Z. Lean thinking in the highways construction sector: Motivation, implementation and barriers. Prod. Plan. Control 2018, 29, 247-269. [CrossRef]

58. Ozcan-Deniz, G.; Zhu, Y. Multi-objective optimization of greenhouse gas emissions in highway construction projects. Sustain. Cities Soc. 2017, 28, 162-171. [CrossRef]

59. Joy, T. A study on factors influencing quality of construction projects. Int. J. Innov. Res. Dev. 2014, 3, 384-387.

60. Lutchmeeduth, B.H.; Kua, H.W.; Gunawansa, A.; Piana, A. Small Islands' Approach to Climate Change Mitigation And Adaptation-The Cases of Mauritius and Singapore. In Proceedings of the Sustainable Green Intelligent Innovative Island, International Conference, Port Louis, Mauritius, 15-19 February 2010.

61. Law, W.C.E. Cutting Green Tape: An Action Plan for Removing Regulatory Barriers to Green Innovations; WCEL: Victoria, BC, Canada, 2002.

62. Newland, J.M. Cost Effective Quality Assurance Practices in Highway Construction. Master's Thesis, East Tennessee State University, Johnson City Tennessee, TN, USA, 2015.

63. Kibert, C.J.; Ries, R.R. Green building education and research at the University of Florida. In Proceedings of the 45th ASC Annual Conference, Gainesville, FL, USA, 1-4 April 2009; pp. 1-132.

64. Rooshdi, R.R.R.M.; Ab Rahman, N.; Baki, N.Z.U.; Majid, M.Z.A.; Ismail, F. An evaluation of sustainable design and construction criteria for green highway. Procedia Environ. Sci. 2014, 20, 180-186. [CrossRef]

65. Robichaud, L.B.; Anantatmula, V.S. Greening project management practices for sustainable construction. J. Manag. Eng. 2010, 27, 48-57. [CrossRef]

66. Samih, H. An Investigation of Sustainability Issue for Building Construction in North Cyprus. J. Environ. Sustain. 2018, 6, 5 .

67. Abidin, N.Z.; Powmya, A. Perceptions on motivating factors and future prospects of green construction in Oman. J. Sustain. Dev. 2014, 7, 231. [CrossRef]

(C) 2019 by the authors. Licensee MDPI, Basel, Switzerland. This article is an open access article distributed under the terms and conditions of the Creative Commons Attribution (CC BY) license (http:/ / creativecommons.org/licenses/by/4.0/). 